\title{
ANALISIS PENGGUNAAN DANA PROGRAM DESA MAJU INHIL JAYA (DMIJ) DENGAN METODE ANALYTICAL HIERARCHY PROCESS
}

\author{
Muh. Rasyid Ridha \\ Jurusan Sistem Informasi, Fakultas Teknik dan Ilmu Komputer, Universitas Islam Indragiri, Tembilahan \\ Email: rasyid4sky@gmail.com
}

\begin{abstract}
The ability to make fast and careful decisions will be the key to success in global competition and to make a decision certainly requires a careful analysis and calculation, depending on the many criteria that affect the problems that require a decision. Taking a decision with many criteria requires a special way of handling. For this reason, a model is needed before a decision is made. The DMIJ Systematics Program is a District Government Program through the Empowerment approach by streamlining the functions of the Village Government, Village Institutions and Village Communities to plan, implement, preserve and supervise development in a participatory manner. To help in solving these problems there needs to be a decision support system. Decision support system is an interactive system that supports decisions in the decision making process through alternatives obtained from the results of data processing, information and model design. AHP is a decision support tool that can be used to solve complex decisions. The application of the AHP method in the development of decision support systems for the use of DMIJ regional government program funds is determined by 4 criteria: infrastructure, welfare, health, and education. The final result of this research is the type of activity that becomes the main priority to be used as a priority for the use of the budget in the DMIJ regional government program is the Supporting Road. Priorities obtained by the Supporting Road (JPN) with a total value of 0.404 or $40.4 \%$. The most influential indicators were Infrastructure at $56.3 \%$, then Kesra at $25.1 \%$, Health $6.1 \%$ and, Education at $12.5 \%$. Keywords : Use of Funds, DMIJ, SPK, AHP
\end{abstract}

\begin{abstract}
Abstrak
Kemampuan mengambil keputusan yang cepat dan cermat akan menjadi kunci keberhasilan dalam persaingan global dan untuk mengambil sebuah keputusan tentu diperlukan analisis analisis dan perhitungan yang matang, tergantung dengan banyak sedikitnya kriteria yang mempengaruhi permasalahan yang membutuhkan suatu keputusan. Pengambilan suatu keputusan dengan banyak kriteria memerlukan suatu cara penanganan khusus. Untuk itu dibutuhkan suatu model sebelum keputusan diambil. Sistematika Program DMIJ adalah Program Pemerintah Kabupaten melalui pendekatan Pemberdayaan dengan mengefektifkan fungsi Pemerintahan Desa, Kelembagaan Desa dan Masyarakat Desa untuk merencanakan, melaksanakan, melestarikan dan pengawasan pembangunan secara partisipatif. Untuk membantu dalam pemecahan masalah tersebut perlu adanya suatu sistem pendukung keputusan. Sistem pendukung keputusan merupakan suatu sistem interaktif yang mendukung keputusan dalam proses pengambilan keputusan melalui alternatif-alternatif yang diperoleh dari hasil pengolahan data, informasi dan rancangan model. AHP adalah alat pendukung keputusan yang dapat digunakan untuk memecahkan suatu keputusan yang kompleks. Penerapan metode AHP dalam pembangunan sistem pendukung keputusan penggunaan dana program pemerintah daerah DMIJ ditetapkan dengan 4 kriteria yaitu: infrastruktur, kesra, kesehatan, dan Pendidikan. Hasil akhir dari penelitian ini yaitu jenis kegiatan yang menjadi prioritas utama untuk dijadikan sebagai prioritas penggunaan anggaran dalam program pemda DMIJ adalah Jalan Penunjang. Prioritas yang di peroleh Jalan Penunjang (JPN) dengan total nilai 0.404 atau $40.4 \%$. Indikator yang paling mempengaruhi adalah Infrastruktur sebesar $56,3 \%$, kemudian Kesra sebesar 25,1\%, Kesehatan 6,1\% dan, Pendidikan sebesar $12,5 \%$.
\end{abstract}

Kata Kunci: Penggunaan Dana, DMIJ, SPK, AHP 


\section{PENDAHULUAN}

Dalam kehidupan sehari hari manusia sering dihadapkan pada suatu keadaan untuk mengambil keputusan. Kemampuan mengambil keputusan yang cepat dan cermat akan menjadi kunci keberhasilan dalam persaingan global dan untuk mengambil sebuah keputusan tentu diperlukan analisis analisis dan perhitungan yang matang, tergantung dengan banyak sedikitnya kriteria yang mempengaruhi permasalahan yang membutuhkan suatu keputusan. Pengambilan suatu keputusan dengan banyak kriteria memerlukan suatu cara penanganan khusus. Untuk itu dibutuhkan suatu model sebelum keputusan diambil.

Program Desa Maju Inhil Jaya yang selanjutnya disebut DMIJ merupakan penjabaran dari visi dan misi Bupati Terpilih. Tujuan umum program DMIJ adalah meningkatkan kesejahteraan dan kesempatan kerja masyarakat dengan mendorong kemandirian dalam pengambilan keputusan dan pengelolaan pembangunan yang berkelanjutan. Dalam penggunaan dana program DMIJ yang berjalan di Desa Nusantara Jaya masih belum adanya suatu sistem pengambilan keputusan yang dapat membantu dalam pengambilan keputusan dalam menggunakan dana program DMIJ. Dan belum adanya suatu aplikasi sistem pendukung keputusan yang digunakan pemerintah daerah dalam mengambilan keputusan penggunaan dana program DMIJ.

Sistematika Program DMIJ adalah Program Pemerintah Kabupaten melalu pendekatan Pemberdayaan dengan mengefektifkan fungsi Pemerintahan Desa, Kelembagaan Desa dan Masyarakat Desa untuk merencanakan, melaksanakan, melestarikan dan pengawasan pembangunan secara partisipatif.

Berdasarkan Perda DMIJ Pasal 4 Ayat (1) Perencanaan pembangunan Desa yang dilaksanakan oleh Pemerintah Desa dalam rangka mewujudkan Program DMIJ disusun melalui musyawarah desa dengan melibatkan partisipasi masyarakat dan kelembagaan desa. Dan berdasarkan Pasal 12 ayat (1)Sumber dana Program DMIJ berasal dari APBD, Ayat(2) Dana Program DMIJ sebagaimana dimaksud pada ayat (1) berasal dari ADD, Dana bagi hasil Pajak dan Retribusi Daerah dan Bantuan Keuangan Kepada Desa. [1]

Untuk membantu dalam pemecahan masalah tersebut perlu adanya suatu sistem pendukung keputusan yang dapat membantu dalam pengambilan suatu keputusan penggunaan dana program DMIJ yang tepat dan dapat memberikan suatu kemudahan untuk mengambil suatu keputusan yang sesuai dengan apa yang dibutuhkan.

Permasalahan yang yang melatarbelakangi penelitian ini diantaranya adalah: a) Seringnya terjadi penyalahgunaan dana program DMIJ dilapangan yang tidak sesuai dengan ketentuan dan peraturan yang telah diterapkan. b) Belum adanya suatu sistem pendukung keputusan yang dapat membantu dalam memecahkan permasalahan penggunaan dana DMIJ, dan c) Belum adanya suatu aplikasi sitem pendukung keputusan yang digunakan pemerintah dalam pegambilan keputusan penggunaan dana program DMIJ.

Tujuan dari penelitian ini adalah: a) Memberikan cara yang mudah dalam pengambilan keputusan yang objektif dari program Desa Maju Inhil Jaya yang didalamnya terdapat persyaratan dan kriteria yang harus dimiliki untuk penggunaan dana program DIMJ. b) Merancang sistem pendukung keputusan penggunaan dana program DIMJ menggunaka metode Analytical Hierarchy Process.

Manfaat yang didapatkan dengan adanya penelitian ini adalah: a) Memberikan kemudahan dalam menentukan penunjang keputusan pengunaan dana program Desa Maju Inhil Jaya. b) Memberikan manajemen yang baik dalam program Desa Maju Inhil Jaya dalam pengunaan dana program Desa Maju Inhil Jaya.

\section{TINJAUAN PUSTAKA}

\subsection{Sistem Pendukung Keputusan}

Konsep Sistem Pendukung Keputusan ditandai dengan sistem yang interaktif dan berbasiskan pada komputer yang dapat membantu pengambilan keputusan memanfaatkan data dan model untuk proses penyelesaian masalah-masalah yang tidak terstruktur. Pada dasarnya Sistem Pendukung Keputusan dirancang untuk mendukung seluruh tahapan pengambilan keputusan di mulai dari pengidentifikasi masalah, memilih data yang relevan, menentukan pendekatan yang digunakan dalam proses pengambilan keputusan, sampai pada tahapan mengevaluasi pemilihan alternatif. [2]

Aplikasi Sistem pendukung keputusan menggunakan data, memberikan antar muka pengguna yang mudah dan dapat menggabungkan pemikiran pengambilan keputusan. Sistem pendukung keputusan lebih ditujukan untuk mendukung manajemen dalam melakukan pekerjaan yang bersifat analitis dalam situasi yang 
kurang terstruktur dan dengan kriteria yang kurang jelas. [3]

Sistem pendukung keputusan merupakan suatu sistem interaktif yang mendukung keputusan dalam proses pengambilan keputusan melalui alternatif-alternatif yang diperoleh dari hasil pengolahan data, informasi dan rancangan model [4]

Menurut McLeod Sistem Pendukung Keputusan adalah suatu sistem berbasis komputer yang menghasilkan berbagai alternatif keputusan untuk membantu manajemen dalam menangani berbagai permasalahan yang terstruktur ataupun tidak terstruktur dengan menggunakan data dan model. [5]

Sistem pendukung keputusan dirancang untuk mendukung seluruh tahap pengambilan keputusan mulai dari mengidentifikasi masalah, memilih data yang relevan, dan menentukan pendekatan yang digunakan dalam proses pengambilan keputusan, sampai mengevaluasi pemilihan alternatif. [6]

Pada dasarnya sistem pendukung keputusan itu merupakan pengembangan lebih lanjut dari sistem terkomputerisasi yang melalui proses perancangan sedemikian rupa dan bersifat interaktif dalam pemakaiannya. Interaktif dimaksudkan untuk memudahkan dalam proses pengambilan keputusan, seperti kebijakan, prosedur, teknik analisis serta pengalaman manajerial guna membentuk suatu kerangka keputusan yang baik. [7]

Sistem Pendukung Keputusan (SPK) merupakan suatu sistem yang menghasilkan alternatif keputusan yang dapat digunakan sebagai alat bantu pengambilan keputusan.

Sehingga dapat disimpulkan bahwa sistem pendukung keputusan adalah suatu sistem berbasis komputer yang dapat menghasilkan alternatif terbaik yang telah ditentukan berdasarkan kriteria-kriteria tertentu untuk membantu para pengambil keputusan dalam menentukan keputusan secara objektif yang lebih cepat dan akurat.

Sistem Pendukung Keputusan terdiri atas tiga komponen utama dalam subsistem diantaranya yaitu: [8] a) Subsistem data (Database), komponen sistem yang mendukung keputusan sebagai penyedia data bagi sistem. Data disimpan dalam rangkaian data (Database) yang diorganisasikan oleh suatu sistem (Database Management System) yang bersumper internal maupun eksternal perusahaan. b) Subsistem Model (Model Base) representasi dari alam nyata. Penyimpanan data kedalam bentuk model dilakukan secara fleksibel untuk membantu pengguna dalam melakukan modifikasi dan menyempurnakan model. c) Subsistem Dialog (User Interface) fasilitas yang digunakan untuk mengintegrasikan pengguna terhadap sistem secara interaktif.

\subsection{Karakteristik dan Kemampuan SPK}

Karakteristik SPK 1. Mendukung seluruh kegiatan organisasi 2. Mendukung beberapa keputusan yang saling berinteraksi 3. Dapat digunakan berulang kali dan bersifat konstan 4. Terdapat dua komponen utama, yaitu data dan model 5. Menggunakan baik data eksternal dan internal 6. Memiliki kemampuan what-if analysis dan goal seeking analysis 7. Menggunakan beberapa model kuantitatif. [9]

Kemampuan SPK 1. Menunjang pembuatan keputusan manajemen dalam menangani masalah semi terstruktur dan tidak terstruktur 2. Membantu manajer pada berbagai tingkatan manajemen, mulai dari manajemen tingkat atas sampai manajemen tingkat bawah 3. Menunjang pembuatan keputusan secara kelompok maupun perorangan 4. Menunjang pembuatan keputusan yang saling bergantung dan berurutan 5. Menunjang tahap-tahap pembuatan keputusan antara lain intelligensi, desain, choice, dan implementation 6 . Kemampuan untuk melakukan adaptasi setiap saat dan bersifat fleksibel 7 . Kemudahan melakukan interaksi system 8. Meningkatkan efektivitas dalam pembuatan keputusan daripada efisiensi 9. Mudah dikembangkan oleh pemakai akhi 10 . Kemampuan pemodelan dan analisis pembuatan keputusan 11 . Kemudahan melakukan pengaksesan berbagai sumber dan format data. [9]

\subsection{Analytical Hierarchy Process}

Triantaphyllou dan Mann menyebutkan bahwa Analytical Hierarchy Process (AHP) merupakan salah satu metode Multi Criteria Decision Making (MCDM) yang dikembangkan oleh Prof Thomas L. Saaty. AHP adalah alat pendukung keputusan yang dapat digunakan untuk memecahkan suatu keputusan yang kompleks. AHP menggunakan struktur hirarki multi-level kriteria, sub-kriteria, dan alternatif (Behaweres et al., 2015).

AHP menawarkan metodologi untuk peringkat tindakan alternatif program berdasarkan penilaian dari pembuat keputusan mengenai pentingnya kriteria dan sejauh mana mereka dipenuhi oleh masingmasing alternatif (Jhon et al., 2013).

AHP mengkolaborasikan beberapa pertimbangan dan penilaian secara pribadi dengan cara yang logis dipengaruhi imajinasi, pengalaman, dan pengetahuan untuk 
menyusun hierarki dari persoalan yang berdasarkan logika, intuisi, dan juga pengalaman untuk memberikan pertimbangan.

\subsubsection{Prinsip Dasar Analytical Hierarchy Process (AHP)}

Dalam menyelesaikan permasalahan dengan AHP ada beberapa prinsip yang harus dipahami, diantaranya adalah:

1. Membuat hierarki

Sistem yang kompleks bisa dipahami dengan memecahnya menjadi elemenelemen pendukung, menyusun elemen secara hierarki, dan menggabungkannya atau mensistensisnya.

2. Penilaian kriteria dan alternatif

Kriteria dan alternatif dilakukan dengan perbandingan berpasangan. Menurut Saaty (1988), untuk berbagai persoalan, skala 1 sampai 9 adalah skala terbaik untuk mengekspresikan pendapat. Nilai dan definisi pendapat kualitatif dari skala perbandingan Saaty bisa diukur menggunakan tabel analisis seperti ditunjukkan pada Tabel berikut.

Tabel 1. Skala Penilaian Perbandingan Pasangan

\begin{tabular}{|c|l|}
\hline Nilai & \multicolumn{1}{|c|}{ Keterangan } \\
\hline 1 & Kedua elemen sama pentingnya \\
\hline 3 & $\begin{array}{l}\text { Elemen yang satu sedikit lebih } \\
\text { penting daripada elemen yang } \\
\text { lainnya }\end{array}$ \\
\hline 5 & $\begin{array}{l}\text { Satu elemen lebih mutlak penting } \\
\text { daripada elemen lainnya }\end{array}$ \\
\hline 7 & $\begin{array}{l}\text { Satu elemen jelas lebih mutlak } \\
\text { penting daripada elemen lainnya }\end{array}$ \\
\hline 9 & $\begin{array}{l}\text { Satu elemen mutlak penting } \\
\text { daripada elemen lainya }\end{array}$ \\
\hline Kebalikan $4,6,8$ & $\begin{array}{l}\text { Nilai-nilai antara dua nilai } \\
\text { pertimbangan yang berdekatan }\end{array}$ \\
\hline & $\begin{array}{l}\text { Jika aktivitas i mendapat satu } \\
\text { angka dibandingkan dengan } \\
\text { aktivitas j, maka j memiliki nilai } \\
\text { kebalikannya dibandingkan } \\
\text { dengan i }\end{array}$ \\
\hline
\end{tabular}

3. Synthesis of priority (menentukan prioritas)

Untuk setiap kriteria dan alternatif, perlu dilakukan perbandingan berpasangan (pairwise Comparisons). Nilai-nilai perbandingan relatif dari seluruh alternatif kriteria bisa disesuaikan dengan judgement yang telah ditentukan untuk menghasilkan bobot dan prioritas. Bobot dan prioritas dihitung dengan memanipulasi matriks atau melalui penyelesaian persamaan matematika.

4. Logical Consistency (Konsistensi Logis)
Konsistensi memiliki dua makna. Pertama, objek-objek yang serupa bisa dikelompokkan sesuai dengan keseragaman dan relevansi. Kedua, menyangkut tingkat hubungan antarobjek yang didasarkan pada kriteria tertentu.

\subsubsection{Prosedur Analytical Hierarchy Process (AHP)}

Pada dasarnya, prosedur atau langkahlangkah dalam metode AHP meliputi:

1. Mendefenisikan masalah dan menentukan solusi yamg diinginkan, lalu menyusun hierarki dari permasalahan yang dihadapi. Penyusun hierarki adalah dengan menetapkan tujuan yang merupakan sasaran sistem secara keseluruhan pada level teratas.

2. Menentukan prioritas elemen

a) Langkah pertama dalam menentukan prioritas elemen adalah membuat perbandingan pasangan, yaitu membandingkan elemen secara berpasangan sesuai kriteria yang diberikan.

b) Matriks perbandingan berpasangan diisi menggunakan bilangan untuk merepresentasikan kepentingan relatif dari suatu elemen terhadap elemen yang lainnya.

3. Sintesis

Pertimbangan-pertimbangan terhadap perbandingan berpasangan di sintesis untuk memperoleh keseluruhan prioritas. Hal-hal yang dilakukan dalam langkah ini adalah:

a) Menjumlahkan nilai-nilai dari setiap kolom pada matriks

b) Membagi setiap nilai dari kolom dengan total kolom yang bersangkutan untuk memperoleh normalisasi matriks.

c) Menjumlahkan nilai-nilai dari setiap basis dan membagikan dengan jumlah elemen untuk mendapatkan nilai ratarata.

4. Mengukur Konsistensi

Dalam pembuatan keputusan, penting untuk mengetahui seberapa baik konsistensi yang ada karena kita tidak menginginkan keputusan berdasarkan pertibangan dengan konsistensi yang rendah. Hal-hal yang dilakukan dalam langkah ini adalah: (a) Kalikan setiap nilai pada kolom pertamadengan prioritas relatif elemen pertama, nilai pada kolom kedua prioritas relatif elemen kedua, dan seterusnya. (b) Jumlah setiap baris. (c) Hasil dari penjumlahan baris dibagi dengan elemen prioritas relatif yang bersangkutan. (d) Jumlah hasil bagi di 
atas dengan banyaknya elemen yang ada, hasil disebut $\lambda$ maks

5. Hitung cinsistency Index (CI) dengan rumus: $\mathbf{C I}=(\boldsymbol{\lambda}$ maks $-\mathbf{n}) / \mathbf{n}$

Di mana $\mathrm{n}=$ banyaknya elemen

6. Hitung rasio konsistensi/consistency ratio (CR) dengan rumus:

\section{$C R=C I / R C$}

Di mana:

$$
\begin{aligned}
& C R=\text { Consistency Ratio } \\
& C I=\text { Consistency Index } \\
& I R=\text { Indeks Random Consistency }
\end{aligned}
$$

7. Memeriksa konsistensi hierarki. Jika nilainya lebih dari $10 \%$, maka penilaian data judgment harus diperbaiki. Namun jika rasio konsistensi (CI/IR) kurang atau sama dengan 0,1, maka hasil perhitungan bisa dinyatakan dengan benar.Daftar indeks Random Konsistensi (IR) bisa dilihat dalam Tabel 2 . berikut:

Tabel 2. Indeks Random Konsistensi

\begin{tabular}{|c|c|}
\hline Ukuran Matriks & Nilai IR \\
\hline 1,2 & 0.00 \\
\hline 3 & 0.58 \\
\hline 4 & 0.90 \\
\hline 5 & 1.12 \\
\hline 6 & 1.24 \\
\hline 7 & 1.32 \\
\hline 8 & 1.41 \\
\hline 9 & 1.45 \\
\hline 10 & 1.49 \\
\hline 11 & 1.51 \\
\hline 12 & 1.48 \\
\hline 13 & 1.56 \\
\hline 14 & 1.57 \\
\hline 15 & 1.59 \\
\hline
\end{tabular}

\section{METODOLOGI PENELITIAN}

Adapun metode yang digunakan untuk mengumpulkan data dalam penelitian yang penulis lakukan antara lain: 1) Observasi, melihat dan mengamati apa saja objek-objek yang harus diperhatikan dalam sebuah penelitian yang penulis buat, dengan tempat Pengamatan dikantor Desa, lokasi sebelas (lokasi) Dusun Desa Nusantara Jaya yang terletak di Kecamatan Keritang. 2) Wawancara, melakukan tanya jawab mengenai apa saja hal yang berkenaan dengan apa yang akan diteliti, mengumpulkan data-data melalui pertanyaan yang telah di konsep terlebih dahulu untuk mencapai sebuah tujuan dalam penelitian. 3) Kuesioner, membuat blangko pertanyaan yang disebar secara acak kepada pihak yang terkait yang terkait dalam hal ini semua Kepala Dusun yang ada di Nusantara Jaya, hasil yang diperoleh nantinya untuk menentukan Perangkingan untuk mendapatkan pilihan Prioritas yang diutamakan untuk mendapatkan bantuan.

Kemudian metode analisis yang digunakan yaitu Metode Simple Additive weighting (SAW). Yaitu dengan: 1) Menentukan kriteria dan alternatif. 2) menentukan bobot-bobot nilai dari setiap keriteria yang ada berdasarkan wawancara dan kuesioner. 3) Melakukan perangkingan terhadap kriteria dan alternatif yang ada untuk mendapatkan hasil dari alternatif dusun yang berprioritas mendapat bantuan.

\section{HASIL DAN PEMBAHASAN}

\subsection{Gambaran Umum}

Desa Nusantara Jaya Adalah Desa yang berada di kecamatan Keritang Kabupaten Indragiri Hilir - Riau berdiri pada tahun 1997 terdiri dari sebelas dusun yaitu dusun Pinang Teluk, Nusantara 1, Usaha Damai, Selamat Abadi, P.4.S Riau, Amanah, Sungai Bulan, Makmur, Nurul Iman, Gemilang Utama, Teluk Dalam. Desa Nusantara Jaya merupakan pemekaran dari desa Kota Baru - Reteh pada tahun 1997, berdasarkan sejarah terbentuknya desa nusantara jaya dilatar belakangi jumlah penduduk yang semakin meningkat, terhambatnya transfortasi untuk melakukan urusan pelayan administrasi karena desa tersebut dibatasi oleh sungai gangsal yang menyulitkan segala urusan pemerintahan desa dan masyarakat. Dengan luas +/- 48,80 KM dengan batas - batas wilayah sebagai berikut :

1. Sebelah Utara berbatasan dengan Desa Lintas Utara

2. Sebelah Selatan berbatasan dengan Desa Kota baru

3. Sebelah Barat berbatasan dengan Desa Mekar Sari

4. Sebelah Barat berbatasan dengan Desa Pabenaan

\subsection{Analisa Proses dan Langkah AHP}

Peralatan utama AHP adalah sebuah hirarki fungsional dengan input utamanya adalah persepsi manusia. Dengan hirarki, suatu masalah kompleks dan tidak terstruktur dipecahkan kedalam kelompokkelompoknya. Langkah-langkah yang dilakukan adalah sebagai berikut:

1) Mendefinisikan Masalah

Pada kasus ini masalah yang ingin dipecahkan dan tujuan yang ingin dicapai ialah ingin mengertahui penggunaan dana program desa maju inhil jaya sesuai dengan kebutuhan yang ada. Dengan membandingkan kriteria-kriteria yang telah ditetapkan. Kriteria-kriteria tersebut adalah: 
infrastruktur, kesra, kesehatan, dan Pendidikan identifikasi masalah tersebut disimpulakan sebagai berikut:

Level 1 : Level Tujuan: Yaitu memilih atau melakukan seleksi untuk penggunaan dana Desa Maju Inhil Jaya yang tepat.

Level 2 : Level Kriteria: Level kriteria yang digunakan dalam sistem pendukung keputusan ini hanya meliputi kriteria-kriteria sebagai berikut: (Infrastruktur: IF, Kesra : KR, Kesehatan : KS dan, Pendidikan : PD) Level 3 : Level Alternatif: Pada level alternatif, alternatif-alternatif yang diambil yaitu indikator yang terdapat pada masingmasing kriteria yang dipilih dan dijadikan alternatif guna mewakili dari pembangunan yang akan dilakukan dengan penggunaan dana DMIJ yang diberikan oleh pemerintah. Alternatif-alternatif tersebut yaitu: a) Jalan Penunjang: JPN, b) Jembatan: JMB, c) Masjid: MSJ, c) Majlis Ta'lim: MJT, d) Rumah Singgah: RMS, dan e) TPA/TPQ: TPQ.

2) Membuat Struktur Hirarki

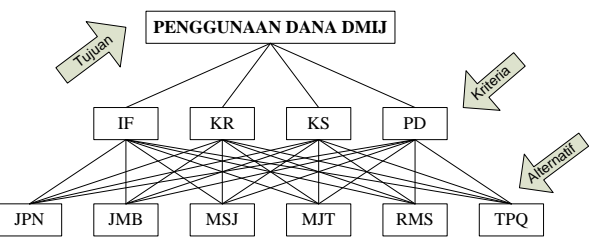

Gambar 1. Hirarki Proses Penggunaan Dana DMIJ

Dari Gambar 1 diatas dapat diketahui bahwa level pertama merupakan level Tujuan: Penggunaan Dana DMIJ. Level kedua adalah kriteria untuk dapat mencapai tujuan utama. Sementara level ketiga merupakan alternatif dari yang digunakan, untuk level kriteria dan alternatif dapat diketahui sebagaimana yang dijelaskan pada langkah pertama.

3) Membuat Matriks Perbandingan Berpasangan

Dalam melakukan penilaian dibentuk matrik perbandingan berpasangan dengan memperhatikan skala penilaian perbandingan berpasangan.

Membandingkan data antar kriteria dalam bentuk matrik berpasangan dengan menggunakan skala intensitas kepentingan AHP. Proses ini dilakukan untuk mengetahui nilai konsistensi rasio perbandingan (CR). Dimana syarat konsistensi harus kecil dari 10 $\%$ atau $\mathrm{CR}<0.1$.

\subsubsection{Perbandingan Berpasangan}

Membandingkan data antar kriteria dalam bentuk matrik berpasangan dengan menggunakan skala intensitas kepentingan
AHP. Proses ini dilakukan untuk mengetahui nilai konsistensi rasio perbandingan (CR). Dimana syarat konsistensi harus kecil dari 10 $\%$ atau $\mathrm{CR}<0.1$.

Tabel 3. Matrik Perbandingan Berpasangan Antar Kriteria

\begin{tabular}{|c|c|c|c|c|}
\hline Kriteria & IF & KR & KS & PD \\
\hline IF & 1 & $\mathrm{IF} / \mathrm{KR}$ & $\mathrm{IF} / \mathrm{KS}$ & $\mathrm{IF} / \mathrm{PD}$ \\
\hline KR & $\mathrm{KR} / \mathrm{IF}$ & 1 & $\mathrm{KR} / \mathrm{KS}$ & $\mathrm{KR} / \mathrm{PD}$ \\
\hline KS & $\mathrm{KS} / \mathrm{IF}$ & $\mathrm{KS} / \mathrm{KR}$ & 1 & $\mathrm{KS} / \mathrm{PD}$ \\
\hline PD & $\mathrm{PD} / \mathrm{IF}$ & $\mathrm{PD} / \mathrm{KR}$ & $\mathrm{PD} / \mathrm{KS}$ & 1 \\
\hline
\end{tabular}

Perhitungan perbandingan berpasangan kriteria nilainya diambil dari hasil analisa 20 responden. Matriks pembobotan hierarki kriteria, nilai input diambil dari tabel hasil penilaian responden, nilai yang diambil adalah nilai tertinggi dari skala Saaty yang paling banyak dipilih oleh responden. Berikut matriks perbandingan tabel 4 .

Tabel 4. Nilai Matrik Perbandingan Kriteria

\begin{tabular}{|c|c|c|c|c|}
\hline Kriteria & IF & KR & KS & PD \\
\hline IF & 1.000 & 3.000 & 7.000 & 5.000 \\
\hline KR & 0.333 & 1.000 & 4.000 & 3.000 \\
\hline KS & 0.143 & 0.250 & 1.000 & 0.333 \\
\hline PD & 0.200 & 0.333 & 3.000 & 1.000 \\
\hline
\end{tabular}

Pada tabel 4, setiap kolom dilakukan perkalian matriks, sehingga diperoleh nilai bobot relatif yang dinormalkan. yaitu sebagai berikut:

Tabel 5. Normalisasi Matrik

\begin{tabular}{|c|r|r|r|r|r|l|}
\hline Kr & IF & KR & KS & PD & $\begin{array}{c}\text { JmI. } \\
\text { Bari } \\
\text { s }\end{array}$ & $\begin{array}{c}\text { Nilai } \\
\text { Eigen }\end{array}$ \\
\hline IF & 0.59 & 0.65 & 0.46 & 0.53 & 2.25 & \\
& 7 & 5 & 7 & 6 & 4 & 0.563 \\
\hline KR & 0.19 & 0.21 & 0.26 & 0.32 & 1.00 & \\
& 9 & 8 & 7 & 1 & 5 & 0.251 \\
\hline KS & 0.08 & 0.05 & 0.06 & 0.03 & 0.24 & \\
& 5 & 5 & 7 & 6 & 2 & 0.061 \\
\hline PD & 0.11 & 0.07 & 0.20 & 0.10 & 0.49 & \\
& 9 & 3 & 0 & 7 & 9 & 0.125 \\
\hline
\end{tabular}

Setelah dihitung bobot prioritas atau nilai eigen-nya, maka dihitung nilai lamda maksimum ( $\lambda$ Maks), yaitu menjumlahkan hasil dari perkalian bobot prioritas dengan jumlah kolom. Maka nilai $\lambda$ Maks yang diperoleh yaitu:

$$
\begin{aligned}
\lambda \text { Maks }= & (1.676 \times 0.563)+(4.583 \times 0.251)+ \\
& (15.000 \times 0.061)+(9.333 \times 0.125)
\end{aligned}
$$

$\lambda$ Maks $=4.169$

$\mathrm{CI}=\frac{\lambda M a k s-\mathrm{n}}{(n-1)}$ 
$C I=\frac{4.169-4}{(4-1)}$

$\mathrm{CI}=\frac{0.169}{3}$

$\mathrm{CI}=0.056$

Untuk n (matrik) $=4, \mathrm{RI}=0.90$ dalam tabel Indeks Random Konsistensi.

$$
\begin{aligned}
& \mathrm{CR}=\frac{C I}{R I} \\
& \mathrm{CR}=\frac{0.056}{0.90} \\
& \mathrm{CR}=0.063
\end{aligned}
$$

Dikarenakan nilai $\mathrm{CR}<$ dari 0.1 maka perbandingan dikatakan konsisten dengan ketentuan: Jika $\mathrm{CR}<0.1$ maka perbandingan konsisten, dan apabila CR $>0.1$ maka perbandingan tidak konsisten.

Hasil perhitungan di atas menunjuk-kan bahwa urutan prioritas kriterianya: Infrastruktur: IF 56,3\%, Kesra : KR 25,1\%, Kesehatan : KS 6,1\% dan, Pendidikan : PD $12,5 \%$.

\subsubsection{Perbandingan Berpasangan antar Alternatif}

Untuk mendapatkan nilai perbandingan matrik pada tiap-tiap alternatif terhadap kriteria-kriteria yang ada, dapat mengacu pada referensi nilai evaluasi yang sudah ada, sehingga peneliti hanya mencocokkan dengan tabel perbandingan Saaty. Berikut ini merupakan matrik perbandingan alternatif berdasarkan kriteria infrastruktur (IF), dapat dilihat pada tabel 6:

Tabel 6. Nilai Matrik Perbandingan Berdasarkan Kriteria Infrastruktur

\begin{tabular}{|c|c|c|c|c|c|c|}
\hline Alt. & JPN & JMB & MSJ & MJT & RMS & TPQ \\
\hline JPN & 1.000 & 3.000 & 5.000 & 7.000 & 7.000 & 3.000 \\
\hline JMB & 0.333 & 1.000 & 3.000 & 7.000 & 7.000 & 1.000 \\
\hline MSJ & 0.200 & 0.333 & 1.000 & 1.000 & 3.000 & 0.333 \\
\hline MJT & 0.143 & 0.143 & 1.000 & 1.000 & 1.000 & 0.200 \\
\hline RMS & 0.143 & 0.143 & 0.333 & 1.000 & 1.000 & 0.250 \\
\hline TPQ & 0.333 & 1.000 & 3.003 & 5.000 & 4.000 & 1.000 \\
\hline
\end{tabular}

Setelah dilakukan penjumlahan pada setiap kolom alternatif (tabel 6), selanjutnya membagi setiap kolom dengan jumlah kolom, maka akan didapat bobot relatif yang dinormalkan. Nilai vector eigen dihasilkan dari rata-rata bobot relatif untuk tiap baris, untuk menghitung jumlah bobot dapat dilihat

\begin{tabular}{|c|c|c|c|c|c|c|}
\hline Alt. & JPN & JMB & MSJ & MJT & RMS & TPQ \\
\hline JPN & $\begin{array}{c}1.000 \\
/ / \\
2.152\end{array}$ & $\begin{array}{c}3.000 \\
/ \\
5.619\end{array}$ & $\begin{array}{c}5.000 \\
/ \\
13.33 \\
6 \\
\end{array}$ & $\begin{array}{c}7.000 \\
/ \\
22.00 \\
0 \\
0\end{array}$ & $\begin{array}{c}7.000 \\
/ \\
23.00 \\
0\end{array}$ & $\begin{array}{c}3.000 \\
/ \\
5.783\end{array}$ \\
\hline JMB & $\begin{array}{c}0.333 \\
/ \\
2.152\end{array}$ & $\begin{array}{c}1.000 \\
/ \\
5.619\end{array}$ & $\begin{array}{c}3.000 \\
/ \\
13.33 \\
6\end{array}$ & $\begin{array}{c}7.000 \\
/ \\
22.00 \\
0 \\
0\end{array}$ & $\begin{array}{c}7.000 \\
/ \\
23.00 \\
0 \\
0\end{array}$ & $\begin{array}{c}1.000 \\
/ \\
5.783\end{array}$ \\
\hline MSJ & $\begin{array}{c}0.200 \\
/ \\
2.152\end{array}$ & $\begin{array}{c}0.333 \\
/ \\
5.619\end{array}$ & $\begin{array}{c}1.000 \\
/ \\
13.33 \\
6 \\
\end{array}$ & $\begin{array}{c}1.000 \\
/ \\
22.00 \\
0 \\
\end{array}$ & $\begin{array}{c}3.000 \\
I \\
23.00 \\
0 \\
\end{array}$ & $\begin{array}{c}0.333 \\
/ \\
5.783\end{array}$ \\
\hline MJT & $\begin{array}{c}0.143 \\
/ \\
2.152\end{array}$ & $\begin{array}{c}0.143 \\
/ \\
5.619\end{array}$ & $\begin{array}{c}1.000 \\
/ \\
13.33 \\
6 \\
\end{array}$ & $\begin{array}{c}1.000 \\
/ \\
22.00 \\
0 \\
\end{array}$ & $\begin{array}{c}1.000 \\
\prime \\
23.00 \\
0 \\
\end{array}$ & $\begin{array}{c}0.200 \\
1 \\
5.783\end{array}$ \\
\hline $\begin{array}{c}\text { RM } \\
\mathbf{S}\end{array}$ & $\begin{array}{c}0.143 \\
/ \\
2.152\end{array}$ & $\begin{array}{c}0.143 \\
/ \\
5.619\end{array}$ & $\begin{array}{c}0.333 \\
/ \\
13.33 \\
6 \\
\end{array}$ & $\begin{array}{c}1.000 \\
/ \\
22.00 \\
0 \\
\end{array}$ & $\begin{array}{c}1.000 \\
I \\
23.00 \\
0 \\
\end{array}$ & $\begin{array}{c}0.250 \\
/ \\
5.783\end{array}$ \\
\hline TPQ & $\begin{array}{c}0.333 \\
/ \\
2.152\end{array}$ & $\begin{array}{c}1.000 \\
/ \\
5.619\end{array}$ & $\begin{array}{c}3.003 \\
/ \\
13.33 \\
6\end{array}$ & $\begin{array}{c}5.000 \\
/ \\
22.00 \\
0 \\
0\end{array}$ & $\begin{array}{c}4.000 \\
\quad \\
23.00 \\
0\end{array}$ & $\begin{array}{c}1.000 \\
/ \\
5.783\end{array}$ \\
\hline
\end{tabular}
pada tabel 7 berikut ini:

Tabel 7. Perhitungan Nilai Eigen

Setelah dilakukan perhitungan nilai eigenyang dapat dilihat pada tabel 7, maka didapatlah hasil pembagian yang dapat dilihat pada tabel 8 digunakan sebagai normalisasi matrik. Untuk normalisasi matrik didapat dari hasil penjumlahan dari jumlah baris alternatif, dan dibagikan dengan jumlah matrik untuk bobot prioritas atau nilai eigennya seperti pada tabel 8 berikut:

Tabel 8. Normalisasi Matrik

\begin{tabular}{|c|c|c|c|c|c|c|c|c|}
\hline Alt. & JPN & JMB & MSJ & MJT & RMS & TPQ & $\begin{array}{c}\text { Jml. } \\
\text { Baris }\end{array}$ & $\begin{array}{c}\text { Nilai } \\
\text { Eigen }\end{array}$ \\
\hline JPN & 0.465 & 0.534 & 0.375 & 0.318 & 0.304 & 0.519 & 2.515 & 0.419 \\
\hline JMB & 0.155 & 0.178 & 0.225 & 0.318 & 0.304 & 0.173 & 1.353 & 0.226 \\
\hline MSJ & 0.093 & 0.059 & 0.075 & 0.045 & 0.130 & 0.058 & 0.461 & 0.077 \\
\hline MJT & 0.066 & 0.025 & 0.075 & 0.045 & 0.043 & 0.035 & 0.290 & 0.048 \\
\hline RMS & 0.066 & 0.025 & 0.025 & 0.045 & 0.043 & 0.043 & 0.249 & 0.041 \\
\hline TPQ & 0.155 & 0.178 & 0.225 & 0.227 & 0.174 & 0.173 & 1.132 & 0.189 \\
\hline
\end{tabular}

Setelah dihitung bobot prioritas atau nilai eigen-nya, maka dihitung nilai lamda maksimum ( $\lambda$ Maks), yaitu menjumlahkan hasil dari perkalian bobot prioritas dengan jumlah kolom. Maka nilai AMaks yang diperoleh yaitu:

$$
\begin{aligned}
\lambda \text { Maks }= & (2.152 \times 0.419)+(5.619 \times 0.226)+ \\
& (13.336 \times 0.077)+(22.000 \times 0.048)+ \\
& (23.000 \times 0.041)+(5.783 \times 0.189)
\end{aligned}
$$

$\lambda$ Maks $=6.303$ 
$\mathrm{CI}=\frac{\lambda M a k s-\mathrm{n}}{(n-1)}$

$C I=\frac{6.303-6}{(6-1)}$

$\mathrm{CI}=\frac{0.303}{5}$

$\mathrm{CI}=0.061$

Untuk n (matrik) $=6, \mathrm{RI}=1.24$ (Tabel Daftar IR Konsistensi).

$\mathrm{CR}=\frac{C I}{R I}$

$\mathrm{CR}=\frac{0.061}{1.24}$

$\mathrm{CR}=0.049$

Dikarenakan nilai $\mathrm{CR}$ < dari 0.1 maka perbandingan dikatakan konsisten dengan ketentuan: Jika CR $<0.1$ maka perbandingan konsisten, dan apabila CR $>0.1$ maka perbandingan tidak konsisten.

Nilai hasil perhitungan dari tiap tiap perbandingan antar alternatif dapat dilihat pada tabel 9.

Tabel 9. Nilai Eigen Alternatif

\begin{tabular}{|c|c|c|c|c|}
\hline \multicolumn{5}{|c|}{ Nilai Eigen Alternatif } \\
\hline Alter. & IF & KR & KS & PD \\
\hline JPN & 0.419 & 0.390 & 0.242 & 0.439 \\
\hline JMB & 0.226 & 0.190 & 0.107 & 0.174 \\
\hline MSJ & 0.077 & 0.106 & 0.139 & 0.070 \\
\hline MJT & 0.048 & 0.129 & 0.142 & 0.061 \\
\hline RMS & 0.041 & 0.107 & 0.073 & 0.053 \\
\hline TPQ & 0.189 & 0.078 & 0.297 & 0.204 \\
\hline
\end{tabular}

Kemudian, total rangking untuk masingmasing alternatif penggunaan anggaran DMIJ dapat dicari dengan cara mengalikan nilai eigen dari masing-masing alternatif dengan nilai eigen kriteria, yakni hasil baris tiap nilai eigen alternatif dikalikan dengan kolom nilai eigen kriteria.

Nilai pada tabel matrik hubungan antar kriteria dengan alternatif ini diambil dari nilai eigen masing-masing alternatif. Untuk hasil matrik pembobotan kriteria normalisasi dapat dilihat pada tabel 10 .

Hasil perhitungan tersebut kemudian dijadikan sebagai hasil keputusan yang digambarkan pada urutan prioritas global penggunaan dana dalam program pemerintah daerah Desa Maju Inhil Jaya (DMIJ) dengan menggunakan metode AHP.

Tabel 10. Prioritas Global

\begin{tabular}{|c|c|c|c|c|c|c|}
\hline \multicolumn{5}{|c|}{ Nilai Eigen Alternatif } & \multirow{2}{*}{$\begin{array}{c}\text { eigen } \\
\text { krit. }\end{array}$} & \multirow{2}{*}{$\begin{array}{c}\text { Eigen } \\
\text { Prioritas }\end{array}$} \\
\hline Alt. & IF & KR & KS & PD & & \\
\hline JPN & 0.419 & 0.390 & 0.242 & 0.439 & 0.563 & 0.404 \\
\hline JMB & 0.226 & 0.190 & 0.107 & 0.174 & 0.251 & 0.203 \\
\hline MSJ & 0.077 & 0.106 & 0.139 & 0.070 & 0.061 & 0.087 \\
\hline MJT & 0.048 & 0.129 & 0.142 & 0.061 & 0.125 & 0.076 \\
\hline RMS & 0.041 & 0.107 & 0.073 & 0.053 & & 0.061 \\
\hline TPQ & 0.189 & 0.078 & 0.297 & 0.204 & & 0.169 \\
\hline \multicolumn{6}{|c|}{ Total Persentase (100\%) } & 1.00 \\
\hline
\end{tabular}

Penjelasan dari tabel 10 diatas yaitu: untuk mencari total rangking untuk masingmasing alternatif penggunaan dana yang akan disetujui adala dengan cara mengalikan nilai eigen masing-masing alternatif dengan nilai eigen kriteria, sehingga didapat suatu kesimpulan dan dijadikan sebagai total prioritas global, dan dijelaskan berikut ini:

$$
\begin{aligned}
J P N= & (0.419 \times 0.563)+(0.390 \times 0.251)+ \\
& (0.242 \times 0.061)+(0.439 \times 0.125) \\
= & 0.404 \\
J M B= & (0.226 \times 0.563)+(0.190 \times 0.251)+ \\
& (0.107 \times 0.061)+(0.174 \times 0.125) \\
= & 0.203 \\
M S J= & (0.077 \times 0.563)+(0.106 \times 0.251)+ \\
& (0.139 \times 0.061)+(0.070 \times 0.125) \\
= & 0.087 \\
= & (0.048 \times 0.563)+(0.129 \times 0.251)+ \\
& (0.142 \times 0.061)+(0.061 \times 0.125) \\
= & 0.076 \\
M J T & (0.041 \times 0.563)+(0.107 \times 0.251)+ \\
& (0.073 \times 0.061)+(0.053 \times 0.125) \\
= & 0.061 \\
R M & (0.189 \times 0.563)+(0.078 \times 0.251)+ \\
& (0.297 \times 0.061)+(0.204 \times 0.125) \\
= & 0.169
\end{aligned}
$$

Dari hasil perhitungan di atas diketahui bahwa urutan prioritas global dari perhitungan penggunaan dana DMIJ yang direkomendasikan diurut berdasarkan nilai perangkingan yang tertinggi yaitu sebagai berikut:

1) Jalan Penunjang (JPN) adalah rangking pertama dengan total nilai 0.404

2) Jembatan (JMB) adalah rangking kedua dengan total nilai 0.203

3) Masjid (MSJ) adalah rangking keempat dengan total nilai 0.087

4) Majlis Ta'lim (MJT) adalah rangking kelima dengan total nilai 0.076

5) Rumah Singgah (RMS) adalah rangking keenam dengan total nilai 0.061 
6) TPA/TPQ (TPQ) adalah rangking ketiga dengan total nilai 0.169

Maka ditarik suatu kesimpulan bahwa yang menjadi rekomendasi untuk penggunaan dana Desa Maju Inhil Jaya (DMIJ) yang lebih diperioritaska adalah Jalan Penunjang (JPN) dengan total nilai 0.404.

\section{KESIMPULAN DAN SARAN}

Berdasarkan hasil penelitian yang telah dilakukan hasil yang diperoleh dalam penggunaan dana program pemerintah Desa Maju Inhil Jaya (DMIJ) menggunakan metode Analytical Hierarchy Process (AHP) maka dapat ditarik beberapa kesimpulan:

1. Hasil perhitungan yang didapat bahwa jenis kegiatan yang menjadi prioritas utama untuk dijadikan sebagai prioritas penggunaan anggaran dalam program pemda DMIJ adalah Jalan Penunjang.

2. Prioritas yang di peroleh Jalan Penunjang (JPN) dengan total nilai 0.404 atau $40.4 \%$. Indikator yang paling mempengaruhi adalah Infrastruktur sebesar 56,3\%, kemudian Kesra sebesar 25,1\%, Kesehatan 6,1\% dan, Pendidikan sebesar $12,5 \%$.

Adapun saran yang dapat diberikan oleh penulis Untuk pengembangan penelitian selanjutnya penulis menyarankan usulan yaitu mengembangkan sistem ini dengan membuat program berbasis desktop dan online sehingga para pengambilan keputusan bisa dengan mudah mengoperasikannya dan melihat hasil dari sistem ini secara terbuka.

\section{DAFTAR PUSTAKA}

[1] Peraturan Daerah Nomor 5 Tahun 2016 Tentang Program Desa Maju Indragiri Hilir Jaya

[2] Batubara, HT, "Rancang Bangun Aplikasi Sistem Pendukung Keputusan Pemilihan Alternatif Tanaman Obat Menggunakan Simple Assitive Weighting", Pelita Informatika Budi Darma, Vol. VII, No.3, 116-121, ISSN: 2301-9525, 2014.

[3] Ardiyanto, Hermawan. Et.al, "Sistem Pendukung Keputusan Pemilihan Perumahan Menggunakan Metode AHP Berbasis WEB (Studi Kasus CV, Wisma Anungkriya Demak)", Journal of Informatics and Technology, Vol. 2, No.3, 1-8, 2013.

[4] Herdiyanti, A., \& Widianti, U. D. Pembangunan Sistem Pendukung Keputusan Rekrutment Pegawai Baru di
PT. $A B C$. Jurnal Ilmiah Komputer dan Informatika (KOMPUTA), 49-56. (2013).

[5] Wedhasmara, A., \& Wibowo, J. A, "Sistem Pendukung Keputusan Pemilihan Pembelian Kendaraan Bermotor Dengan Metode SAW", Jurnal Sistem Informasi (JSI), 246-257, 2010

[6] Ridha, M. R., "Model Analytical Hierarchy Procces Untuk Penilaian Desa Dalam Program Desa maju Inhil Jaya", Jurnal SISTEMASI, vol. 6, no. 1, E-ISSN:25409717, 14-19, 2017.

[7] Kurniasih, D. L., "Sistem Pendukung Keputusan Pemilihan Laptop dengan Metode TOPSIS", Pelita Informatika Budi Darma, Vol. III, No. 2, ISSN: 23019425, 6-13, 2013

[8] Nugraha, F., "Sistem Pendukung Keputusan Dengan Metode Simple additive weigthing (SAW) dalam Manajemen Aset", Semarang, 2011.

[9] Kurniasih, DL, "Sistem Pendukung Keputusan Pemilihan Laptop dengan Metode TOPSIS", Pelita Informatika Budi Darma, Vol. III, No.2, 6-13, ISSN: 23019525, 2013.

[10] Bahaweres, R., Budiyanto, F. I., dan Antonyova, A. AHP (Analytical Hierarchy Process) Electoral College Majors in Indonesia Based on Android Mobile. ARPN Journal of Engineering and Appied Sciences , 457-466. 2015.

[11] Jhon, K., Baby, V. Y., dan Mangalthu, G. S. Vendor Evaluation and Rating Using analytical Hierarchy Process. IJESIT , 447-451. 2013 